\title{
AFFERENT LOOP VOLVULUS WITH A GROSSLY ELEVATED SERUM AMYLASE
}

\author{
By Roy York Calne, M.B., F.R.C.S. \\ The Royal Free Hospital, W.C.I
}

This case is recorded because of several unusual features and especially on account of the markedly raised serum amylase that led to a wrong diagnosis.

\section{Case Report}

A woman of 39 was admitted to the Royal Free Hospital under Miss G. Barry with a history of eight hours' severe upper abdominal pain and repeated bilious vomiting. Three years previously she had had an ante-colic Polya type gastrectomy for haematemasis and melaena resulting from multiple superficial gastric erosions. Since operation, she had suffered from several attacks of epigastric pain and bilious vomiting, similar in character to the present illness, but less severe. She was investigated a year previously and no abnormality could be found to account for her symptoms. A barium meal examination showed a well functioning stoma and a normal afferent loop.

The present attack started at 2 p.m., following ingestion of a sandwich, with very severe epigastric pain radiating to the back on both sides and repetitive vomiting of bile stained gastric contents. She was given an injection of $\frac{1}{4} \mathrm{gr}$. (16 mg.) of morphia subcutaneously at 5.30 p.m. by her own doctor. The pain was constant, but with acute exacerbations. It was not affected by posture. The patient was not an alcoholic.

On examination she was a thin pale woman. Her temperature was $98^{\circ} \mathrm{F} .\left(36.6^{\circ} \mathrm{C}\right.$.), her pulse rate 60 and her blood pressure $115 / 90$ m.m. Hg. She was tender in the epigastrium. There were no other abnormal signs. A provisional diagnosis of an 'Afferent Loop Syndrome' was made. In view of her vomiting a gastric tube was passed and an intravenous infusion was set up. Serum was taken at ro p.m. for amylase estimation to exclude pancreatitis.

Twelve hours later the patient's condition had deteriorated, her pain had increased, her pulse rate had risen to 90 and she had developed rigidity with guarding in the upper abdomen. No gut sounds could be heard. The serum amylase was
3000 units (Somogyi) per $100 \mathrm{ml}$. It was therefore assumed that she had acute pancreatitis and she was treated with penicillin, streptomycin, propantheline (' pro-banthine ') and pethidine. However her condition became worse and she was given hydrocortisone. A further serum amylase at II a.m., thirteen hours after the first, was 490 units. She died in peripheral failure forty-four hours after admission.

The relevant findings at autopsy, which was performed by Dr. I. Filchie, were volvulus and gangrene of the afferent loop of jejunum and generalized peritonitis. The pancreas looked normal macroscopically. Microscopy showed post-mortem autolysis with no evidence of acute pancreatitis.

\section{Discussion}

Although a variety of abdominal emergencies may cause a rise in the serum amylase, ${ }^{5}$ it is generally accepted that a serum amylase of over 500 units (Somogyi) per $100 \mathrm{ml}$. is good evidence in favour of pancreatitis and over 1000 units renders an alternative diagnosis unlikely. Thus a level of 3000 units and a clinical picture consistent with severe acute pancreatitis prevented serious consideration of any alternative, although in the absence of the raised amylase, the undiagnosed peritonitis would obviously have called for an urgent laparotomy. In retrospect, either or both of the following considerations may explain the high serum amylase:-

(I) Morphine and its derivatives can cause a rise in the serum amylase. ${ }^{2,3,6}$ In a case quoted by Gross et al., ${ }^{4}$ a level of 4,000 units was produced four hours after a subcutaneous injection of $2 \mathrm{gr}$. (130 mg.) of codeine phosphate.

(2) A closed loop obstruction of the bowel segment into which the pancreas drains may well have greatly increased the intra-pancreatic pressure, thereby raising the serum enzyme level.

Thus doubt is cast on the diagnostic value of the serum amylase and early laparotomy whenever 
there are signs of upper abdominal peritonitis would appear to be indicated in spite of the undesirability of operation in acute pancreatitis. ${ }^{1}$

I thank Miss G. Barry, M.S., F.R.C.S., for permission to write this report and Dr. D. N. Baron, M.D., for checking the method of the serum amylase estimation.
REFERENCES

I. BOCKUS, H. L., KALSER, M. H., ROTH, J. L. A., BOGOCH, A. L., and STEIN, M.D. (1955), Arch. Int. Med., 96, 308.

2. BOGOCH, A., ROTH, J. L. A., and BOCKUS, H. L. (1954),

Gastroenterology, 26, 697 .
3. BURK, J. O., PLUMMER,

Ibid., 15, 699.

GROSS, J. B., COMFORT, M. W., MATHIESON, D. R., and

POWER, M. H. (1951), Proc. Staff. Meet., Mayo Ćlin., 26, 81 .

5. POLLOCK, A. V. (1959), Brit. med. F., i, 6.

6. WAPSHAW, H. (1953), Ibid., i, 373.

\section{HOW TO GET THERE}

An Address Book for the Medical profession, showing how to reach the various Colleges, Societies, Institutes and Hospitals in or near London

New (Fifth) Edition: 1960

4s. 6d. post free

Published by the

FELLOWSHIP OF POSTGRADUATE MEDICINE

60 Portland Place, London, W.I 